\title{
ANALISIS KESALAHAN BERBAHASA DALAM TATARAN MORFOLOGI PADA PORTAL BERITA ONLINE SUARA.COM
}

\author{
Arlita Andriani ${ }^{1}$ \\ Diana Intan Sari ${ }^{2}$ \\ Elisa Mifta Choirunisa ${ }^{3}$ \\ Natasya Puteri Ariska ${ }^{4}$ \\ Chafit Ulya ${ }^{5}$
}

\begin{abstract}
ABSTRAK
Sebagai penyalur berita ke masyarakat, Suara.com juga tidak luput dari kesalahan berbahasa dalam menulis dan menyiarkan berita. Penelitian ini bertujuan untuk menganalisis kesalahan morfologi yang terdapat pada artikel surat kabar online Suara.com. Sumber data yang digunakan sebagai objek analisis menggunakan sumber data dari portal berita online Suara.com. Di dalam penelitian ini menggunakan pendekatan kualitatif dan metode analisis isi untuk menganalisis kesalahan morfologi. Teknik yang digunakan dalam penelitian ini adalah membaca dan menulis. Hasil dari penelitian ini adalah analisis kesalahan berbahasa dalam bidang morfologi meliputi: 1.) Kesalahan penggunaan afiksasi, 2.) Penulisan kata baku, 3.) Afiksasi yang tidak luluh, 4.) Kata majemuk, dan 5.) Proses reduplikasi.
\end{abstract}

Kata Kunci: Analisis kesalahan berbahasa, Morfologi, Suara.com

\section{ABSTRACT}

As a distributor of news to the public, Suara.com is also not free from language errors in writing and broadcasting news. This study aims to analyze the morphological errors found in Suara.com online newspaper articles. The data source used for object analysis is the data source from the online news portal Suara.com. In this study, a qualitative approach and content analysis methods were used to analyze morphological errors. The technique used in this research is reading and writing. The results of this study are the analysis of language errors in the field of morphology including: 1.) errors in using affixation, 2.) writing standard words, 3.) affixation that does not melt, 4.) compound words, and 5.) reduplication process.

Keywords: Language error analysis, Morphology, Suara.com

\footnotetext{
${ }^{1}$ Mahasiswa Universitas Sebelas Maret, email: arlita_andriani14@student.uns.ac.id

${ }^{2}$ Mahasiswa Universitas Sebelas Maret, email: dintan344@student.uns.ac.id

${ }^{3}$ Mahasiswa Universitas Sebelas Maret, email: elisa.mifta@student.uns.ac.id

${ }^{4}$ Mahasiswa Universitas Sebelas Maret, email: natasyaputeri18@student.uns.ac.id

${ }^{5}$ Dosen Universitas Sebelas Maret, email: chafit@staff.uns.ac.id
} 


\section{PENDAHULUAN}

Bahasa sebagai alat komunikasi menjadi kebutuhan pokok yang harus dimengerti oleh setiap individu. Bahasa merupakan sebuah alat komunikasi terorganisasi dalam bentuk satuan kata, klausa, dan kalimat yang diungkapkan secara lisan atau tulis (Wiratno \& Santosa, 2011). Berbeda dengan sebelumnya, bahasa menurut (Dewi, 2020) merupakan sesuatu yang dimiliki manusia tidak pernah lepas dari kegiatan dan gerak manusia sebagai makhluk yang berbudaya dan bermasyarakat. Berdasarkan uraian sebelumnya, bahasa adalah lambang bunyi bersifat manusiawi yang berpola dan berisi kaidah tertentu dengan unsur-unsur yang terbatas serta dapat berubah kapanpun. Menurut (Sitepu \& Rita, 2017), bahasa sebagai suatu sistem, yang bersifat arbitrer, produktif, dinamis, beragam, dan manusiawi. Begitu kompleksnya sistem dalam berbahasa, sehingga harus dipelajari agar tidak melakukan kesalahan dalam berbahasa.

Seperti kebanyakan, kesalahan berbahasa juga dapat dianalisis untuk dijadikan sebagai pengembang taraf pengetahuan berbahasa seseorang. Analisis kesalahan berbahasa adalah salah satu cara untuk menggunakan bahasa Indonesia yang baik dan benar (Indihadi, 2011). Badudu (1982) dalam (Dewi, 2020) menyatakan bahwa analisis kesalahan berbahasa dalam bidang morfologi merupakan analisis kesalahan yang meliputi kesalahan afiksasi, kesalahan reduplikasi, dan kesalahan pemajemukan (komposisi). Analisis kesalahan berbahasa dilakukan guna bertujuan untuk memperbaiki komponen dalam proses kegiatan belajar dan mengajar bahasa Indonesia yang baik dan benar.
Pada kenyataannya, hingga detik ini kesalahan berbahasa masih bermunculan di berbagai media terutama pada media berita online. Pada kesempatan kali ini, penulis akan menganalisis kesalahan berbahasa menggunakan objek kajian morfologi pada media berita online Suara.com. Media tersebut akan dianalisis berdasarkan aspekaspek morfologi, antara lain meliputi: penulisan kata baku pada berita, kesalahan penggunaan kalimat majemuk, kesalahan penggunaan afiksasi, dan kesalahan reduplikasi. Kesalahan dalam berbahasa tidak boleh hanya dibiarkan saja dan harus segera ditangani. Ketika kesalahan berbahasa pada media online tidak dikaji, akan menimbulkan masalah pada pembacanya. Seharusnya media online dapat mengedukasi pembaca dengan baik, sehingga akan terciptanya pengetahuan berbahasa yang benar. Berdasarkan pernyataan sebelumnya, sudah terlihat jelas bahwa tujuan dari penelitian ini yaitu untuk menganalisis kesalahan morfologi pada berita online Suara.com.

Bidang Linguistik yang mengkaji tentang proses pembentukan kata yakni bidang morfologi. Melalui penelitian yang telah dilakukan oleh M. Rais Almajid, Dkk berjudul "Analisis Kesalahan Afiks Pada Berita Babe.com Periode Januari-April 2020" menyatakan media massa merupakan salah satu media yang berpotensi mempengaruhi pemahaman bahasa manusia dan berfungsi menjadi jalur guna melakukan pembinaan dan pengembangan bahasa Indonesia yang baik dan benar. Kesalahan sering ditemukan dalam proses pembentukan kata atau kesalahan yang berpotensi mengubah makna dan bentuk kata. Pada penelitian yang ditulis oleh M.Rais Almajid, Dkk tersebut mengkaji 
kesalahan berbahasa pada bidang morfologi yang fokusnya pada afiksasi atau penambahan imbuhan berupa kesalahan prefiks, kesalahan konfiks dan kesalahan sufiks pada berita Babe.com Periode Januari-April 2020, setelah diteliti oleh penulis, dapat ditarik kesimpulan bahwa kesalahan terbanyak terletak pada kesalahan konfiks. Berdasarkan hal itu, dapat diartikan bahwa berita daring perlulah diamati terkait dengan struktur kalimat maupun ejaannya sehingga penulis mengangkat "Analisis Kesalahan Berbahasa dalam Tataran Morfologi pada Portal Berita Online Suara.com"

\section{METODE PENELITIAN}

Penelitian ini menggunakan pendekatan deskriptif kualitatif dengan metode analisis isi. Data yang digunakan dalam penelitian ini yaitu kata yang mengandung kesalahan berbahasa dalam bidang morfologi pada berita online. Sumber data yang digunakan berupa berita dalam portal berita online Suara.com. Teknik pengumpulan data yang digunakan penulis dalam penelitian ini yaitu teknik baca dan catat. Penulis membaca berita-berita yang ada dalam portal berita online Suara.com kemudian mencatat bagian-bagian yang terdapat kesalahan berbahasa dalam bidang morfologi. Teknik analisis data dalam penelitian ini yaitu teknik reduksi data, penyajian data dan penarikan simpulan. Setelah mencatat bagian-bagian yang memiliki kesalahan berbahasa dalam bidang morfologi, penulis kemudian mereduksi data tersebut dan menyesuaikan juga mengelompokkan kesalahan berdasarkan tataran morfologi. Data kemudian disajikan dalam bentuk deskripsi. Pada bagian akhir, penulis menarik kesimpulan dari data yang telah dianalisis.

\section{HASIL DAN PEMBAHASAN}

Dalam berbahasa tidak semua orang mampu menggunakan bahasa dengan baik dan benar, karena pada dasarnya setiap orang memiliki kompetensi yang berbedabeda. Hal ini tentunya tergantung dari kebiasaan dari diri sendiri. Jika seorang anak dibiasakan menggunakan bahasa dengan baik dan benar, tentu anak tersebut akan membawa kebiasaannya ke tempat yang lain. Namun, jika lingkungan sekitarnya memberikan dampak yang buruk pada bahasanya, maka besar kemungkinan anak tersebut akan terkena dampaknya. Hal ini ada kaitannya dengan morfologi .

Morfologi adalah ilmu yang membahas mengenai bentuk-bentuk dan pembentukan kata, di dalam artikel ini yang dimaksud dengan analisis kesalahan berbahasa dalam morfologi adalah sebuah kegiatan menganalisis kesalahan tentang pembentukan kata yang menyimpang dari kaidah di dalam aturan tata bahasa Indonesia.

Dalam penulisan banyak kesalahan yang dilatar belakangi dengan kesalahan penulisan, penggunaan susunan kalimat dan luputnya editor dalam proses penyuntingan naskah, banyak dijumpai salah ketik, dan penggunaan spasi yang seharusnya juga diperhatikan dalam penggunaan bahasa yang baik dan benar. Di dalam artikel penelitian ini kita akan membahas mengenai teknik menulis dan menyusun kata yang digunakan dalam penelitian ini. Analisis kesalahan berbahasa yang akan dibahas dalam artikel ini ialah:

1) Kesalahan penggunaan afiksasi, mencakup penambahan ejaan atau kata sambung yang dinilai tidak cocok dan tidak sesuai dengan ejaan yang sudah ditentukan 
2) Penulisan kata baku, yang mencakup mengenai kesalahan penulisan ejaan, kata yang kurang cocok dan penggunaan kata yang kurang tepat

3) Afiksasi yang tidak luluh, dimana imbuhan yang ditambahkan kurang cocok sehingga secar bacaan menjadi salah dan tidak sesuai dengan kaidah bahasa indonesia.

4) Kata majemuk, mencakup kesalahan penulisan dipisah atau digabung yang seharusnya sesuai dengan ejaan bahasa indonesia yang tepat

5) Proses reduplikasi, dimana reduplikasi ialah suatu pengulangan satuan gramatik, baik seluruhnya maupun sebagian, baik dengan variasi fonem maupun tidak.

Berikut analisis kesalahan berbahasa dalam tataran morfologi yang telah dilakukan oleh penulis pada portal berita online Suara.com. Berikut ini merupakan penjelasan terkait analisis kesalahan berbahasa yang telah dilakukan.

\section{A. Penulisan Kata Baku}

Kesalahan dalam kategori penulisan kata baku pada portal berita online Suara.com. Dalam kategori ini, ditemukan lima kesalahan penulisan kata baku dari beberapa judul berita. Kesalahan penulisan kata baku dalam portal berita online Suara.com yang telah dianalisis menunjukkan kesalahan kebanyakan dikarenakan kurangnya huruf dalam suatu kata. Berikut ini tabel analisis kesalahan penulisan kata baku dalam portal berita online Suara.com yang telah ditemukan.

Tabel 1. Kesalahan Penulisan Kata

\begin{tabular}{|c|c|c|c|c|}
\hline No. & Publikasi & Judul Berita & Kalimat & Kesalahan \\
\hline 1. & $\begin{array}{l}\text { Rabu, } 10 \\
\text { November } \\
2021 \text {, } \\
\text { 19:09 WIB }\end{array}$ & $\begin{array}{l}\text { Khidmat } \\
\text { Upacara } \\
\text { Bendera Hari } \\
\text { Pahlawan di } \\
\text { Pontren } \\
\text { Syaikh } \\
\text { Zainuddin } \\
\text { NW Anjani }\end{array}$ & $\begin{array}{l}\text { Dalam amanat } \\
\text { Menteri Sosial, } \\
\text { Tri } \\
\text { Rismaharani } \\
\text { yang dibacakan } \\
\text { Inspektur } \\
\text { Upacara } \\
\text { mengajak } \\
\text { masyarkat } \\
\text { Indonesia } \\
\text { mencotoh } \\
\text { semangat } \\
\text { perjuangan para } \\
\text { pahlawan } \\
\text { pendulu kita } \\
\text { dalam merebut } \\
\text { kemerdekaan } \\
\text { setelah ratusan } \\
\text { tahun dijajah. }\end{array}$ & masyarkat \\
\hline \multicolumn{5}{|c|}{$\begin{array}{l}\text { Dalam kalimat tersebut terdapat kesalahan pada penulisan kata baku. } \\
\text { Penulisan kata "masyarkat" dalam portal berita online Suara.com yang } \\
\text { berjudul "Khidmat Upacara Bendera Hari Pahlawan di Pontren Syaikh } \\
\text { Zainuddin NW Anjani" kurang tepat dan tidak sesuai dengan KBBI. } \\
\text { Seharusnya ada huruf a setelah huruf r. Jadi yang benar adalah } \\
\text { "masyarakat". }\end{array}$} \\
\hline 2. & $\begin{array}{l}\text { Rabu, } 29 \\
\text { September } \\
2021 \text {, } \\
\text { 19:11 WIB }\end{array}$ & $\begin{array}{l}\text { Bertemu } \\
\text { Dubes } \\
\text { Belanda, } \\
\text { Gubernur } \\
\text { Jateng Bahas } \\
\text { soal } \\
\text { Penanganan } \\
\text { Banjir }\end{array}$ & $\begin{array}{l}\text { Selain itu, } \\
\text { dirinya juga } \\
\text { telah } \\
\text { mendengar } \\
\text { banyal hal yang } \\
\text { telah dilakukan } \\
\text { pemerintah } \\
\text { dalam usaha } \\
\text { menanggulangi } \\
\text { banjir. }\end{array}$ & banyal \\
\hline \multicolumn{5}{|c|}{$\begin{array}{l}\text { Pembetulan: } \\
\text { Dalam kalimat tersebut terdapat kesalahan pada penulisan kata baku. } \\
\text { Penulisan kata "banyal" dalam portal berita online Suara.com yang } \\
\text { berjudul "Bertemu Dubes Belanda, Gubernur Jateng Bahas soal } \\
\text { Penanganan Banjir" kurang tepat dan tidak sesuai dengan KBBI. } \\
\text { Seharusnya yang benar menggunakan huruf k di akhir dan bukan } \\
\text { hururf 1. Jadi yang benar adalah "banyak". }\end{array}$} \\
\hline
\end{tabular}

Baku 
Volume 2, Nomor 2, Desember 2021

\begin{tabular}{|c|c|c|c|c|}
\hline 3. & $\begin{array}{l}\text { Rabu, } 29 \\
\text { September } \\
2021 \text {, } \\
\text { 19:11 WIB }\end{array}$ & $\begin{array}{l}\text { Bertemu } \\
\text { Dubes } \\
\text { Belanda, } \\
\text { Gubernur } \\
\text { Jateng Bahas } \\
\text { soal } \\
\text { Penanganan } \\
\text { Banjir }\end{array}$ & $\begin{array}{l}\text { Dan juga } \\
\text { tentang } \\
\text { tantangan yang } \\
\text { dimiliki } \\
\text { Gubernur Jawa } \\
\text { Tengah serta } \\
\text { pemerintah } \\
\text { yang sangat } \\
\text { banyak terkait } \\
\text { menejemen } \\
\text { perairan atau } \\
\text { banjir," ujar } \\
\text { Lambert. }\end{array}$ & menejemen \\
\hline \multicolumn{5}{|c|}{$\begin{array}{l}\text { Dalam kalimat tersebut terdapat kesalahan pada penulisan kata baku. } \\
\text { Penulisan kata "menejemen" dalam portal berita online Suara.com } \\
\text { yang berjudul "Bertemu Dubes Belanda, Gubernur Jateng Bahas soal } \\
\text { Penanganan Banjir" kurang tepat dan tidak sesuai dengan KBBI. } \\
\text { Penulisan yang kata "menejemen" yang benar ialah "manajemen". }\end{array}$} \\
\hline & $\begin{array}{l}\text { Rabu, } 10 \\
\text { November } \\
2021 \text {, } \\
\text { 19:02 WIB }\end{array}$ & $\begin{array}{l}63 \text { Persen } \\
\text { Lebih } \\
\text { Masyarakat } \\
\text { Kota Solok } \\
\text { Sudah } \\
\text { Divaksin }\end{array}$ & $\begin{array}{l}\text { Secara } \\
\text { segmentasi, } \\
\text { capain } \\
\text { pelaksanaan } \\
\text { vaksinasi } \\
\text { Covid-19 di } \\
\text { Kota Solok } \\
\text { paling tinggi } \\
\text { berada di target } \\
\text { remaja. }\end{array}$ & capain \\
\hline \multicolumn{5}{|c|}{$\begin{array}{l}\text { Pembetulan: } \\
\text { Dalam kalimat tersebut terdapat kesalahan pada penulisan kata baku. } \\
\text { Penulisan kata "capain" dalam portal berita online Suara.com yang } \\
\text { berjudul "63 Persen Lebih Masyarakat Kota Solok Sudah Divaksin" } \\
\text { kurang tepat dan tidak baku. Seharusnya sebelum huruf n ada huruf a. } \\
\text { Sehingga penulisan yang baku ialah "capaian". }\end{array}$} \\
\hline & $\begin{array}{l}\text { Rabu, } 10 \\
\text { November } \\
2021 \text {, } \\
\text { 18:39 WIB }\end{array}$ & $\begin{array}{l}\text { Jurnalis TV } \\
\text { Nasional Jadi } \\
\text { Korban } \\
\text { Pelecehan } \\
\text { Seksual di } \\
\text { Pasar } \\
\text { Rawajati }\end{array}$ & $\begin{array}{l}\text { FK sempat } \\
\text { berupaya } \\
\text { mengejarnya } \\
\text { untuk } \\
\text { memvediokan } \\
\text { wajah pelaku. }\end{array}$ & $\begin{array}{l}\text { memvedio } \\
\text { kan }\end{array}$ \\
\hline
\end{tabular}

Pembetulan:

Dalam kalimat tersebut terdapat kesalahan pada penulisan kata baku. Penulisan kata "memvediokan" dalam portal berita online Suara.com yang berjudul "Jurnalis TV Nasional Jadi Korban Pelecehan Seksual di Pasar Rawajati" kurang tepat dan tidak baku. Kata "memvediokan" berasal dari kata dasar video, jadi seharusnya penulisan yang sesuai dengan KBBI setelah mendapatkan afiks kata video menjadi "memvideokan".

\section{B. Penggunaan Kalimat Majemuk}

Tabel 2. Kesalahan Penggunaan Kalimat Majemuk

Kesalahan dalam kategori penulisan kalimat majemuk pada portal berita online Suara.com. Dalam kategori ini, ditemukan lima kesalahan penulisan kalimat majemuk dari beberapa judul berita. Kesalahan penulisan kalimat majemuk dalam portal berita online Suara.com yang telah dianalisis menunjukkan kesalahan kebanyakan dikarenakan penulisan kalimat yang harusnya digabung, tetapi malah dipisah. Berikut ini tabel analisis kesalahan penulisan kalimat majemuk dalam portal berita online Suara.com yang telah ditemukan. 
Volume 2, Nomor 2, Desember 2021

\begin{tabular}{|c|c|c|c|c|}
\hline $\begin{array}{l}\mathrm{N} \\
\mathrm{o}\end{array}$ & $\begin{array}{l}\text { Publi } \\
\text { kasi }\end{array}$ & $\begin{array}{l}\text { Judul } \\
\text { Berita }\end{array}$ & Kalimat & Kesalahan \\
\hline & $\begin{array}{l}\text { Rabu, } 29 \\
\text { September } \\
2021 \mid \\
\text { 19:11 WIB }\end{array}$ & $\begin{array}{l}\text { Bertemu } \\
\text { Dubes } \\
\text { Belanda, } \\
\text { Gubernur } \\
\text { Jateng } \\
\text { Bahas soal } \\
\text { Penangana } \\
\text { n Banjir }\end{array}$ & $\begin{array}{l}\text { “Terimakasih } \\
\text { kami } \\
\text { sampaikan } \\
\text { kepada } \\
\text { Bapak } \\
\text { Gubernur } \\
\text { atas } \\
\text { sambutan } \\
\text { yang sangat } \\
\text { impresif. Dan } \\
\text { juga tentang } \\
\text { tantangan } \\
\text { yang dimiliki } \\
\text { Gubernur } \\
\text { Jawa Tengah } \\
\text { serta } \\
\text { pemerintah } \\
\text { yang sangat } \\
\text { banyak } \\
\text { terkait } \\
\text { menejemen } \\
\text { perairan atau } \\
\text { banjir," ujar } \\
\text { Lambert. }\end{array}$ & $\begin{array}{l}\text { Terimakasi } \\
\mathrm{h}\end{array}$ \\
\hline \multicolumn{5}{|c|}{ Pembetulan: } \\
\hline \multicolumn{5}{|c|}{$\begin{array}{l}\text { Pada kalimat tersebut terdapat kesalahan pada penggunaan } \\
\text { kalimat majemuk. Kalimat pada berita berjudul "Bertemu Dubes } \\
\text { Belanda, Gubernur Jateng Bahas soal Penanganan Banjir" pada } \\
\text { portal berita Suara.com tersebut kurang tepat, pada berita tersebut } \\
\text { tertulis kata "terimakasih" digabung, harusnya ditulis secara } \\
\text { terpisah sesuai dengan kaidah bahasa Indonesia. Pembetulannya } \\
\text { menjadi "terima kasih" }\end{array}$} \\
\hline
\end{tabular}

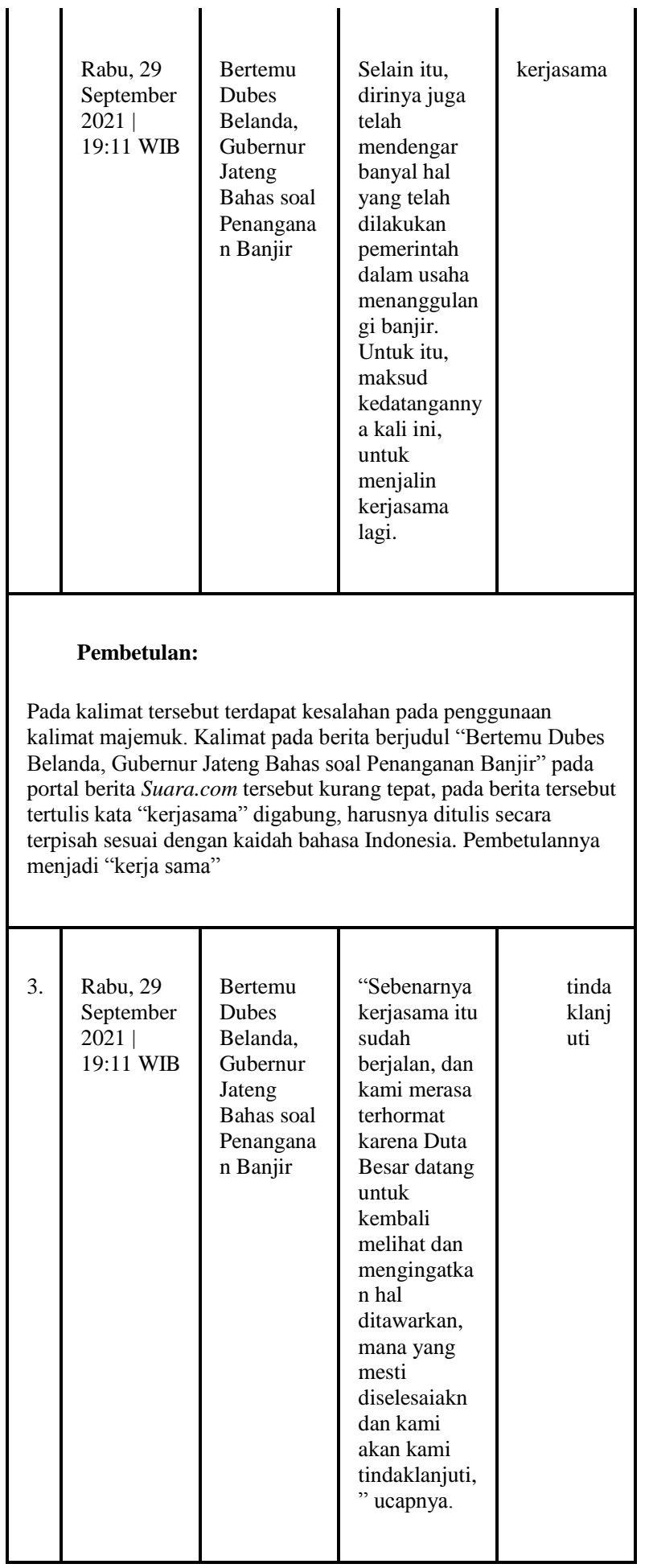


Volume 2, Nomor 2, Desember 2021

Pembetulan:

Pada kalimat tersebut terdapat kesalahan pada penggunaan kalimat majemuk. Kalimat pada berita berjudul "Bertemu Dubes Belanda, Gubernur Jateng Bahas soal Penanganan Banjir" pada portal berita Suara.com tersebut kurang tepat, pada berita tersebut tertulis kata "tindaklanjuti" digabung, harusnya ditulis secara terpisah sesuai dengan kaidah bahasa Indonesia. Pembetulannya menjadi "ditindak lanjuti"

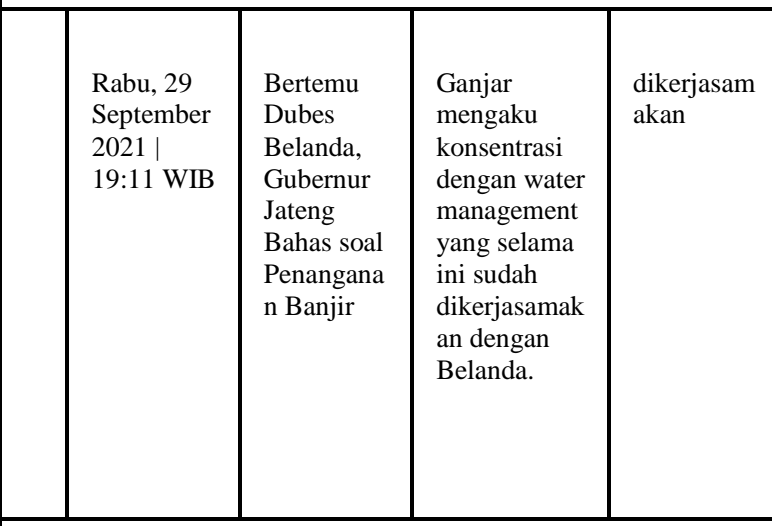

Pembetulan

Pada kalimat tersebut terdapat kesalahan pada penggunaan kalimat majemuk. Kalimat pada berita berjudul "Bertemu Dubes Belanda, Gubernur Jateng Bahas soal Penanganan Banjir" pada portal berita Suara.com tersebut kurang tepat, pada berita tersebut tertulis kata "dikerjasamakan digabung, harusnya ditulis secara terpisah sesuai dengan kaidah bahasa Indonesia. Pembetulannya menjadi "dikerja samakan"

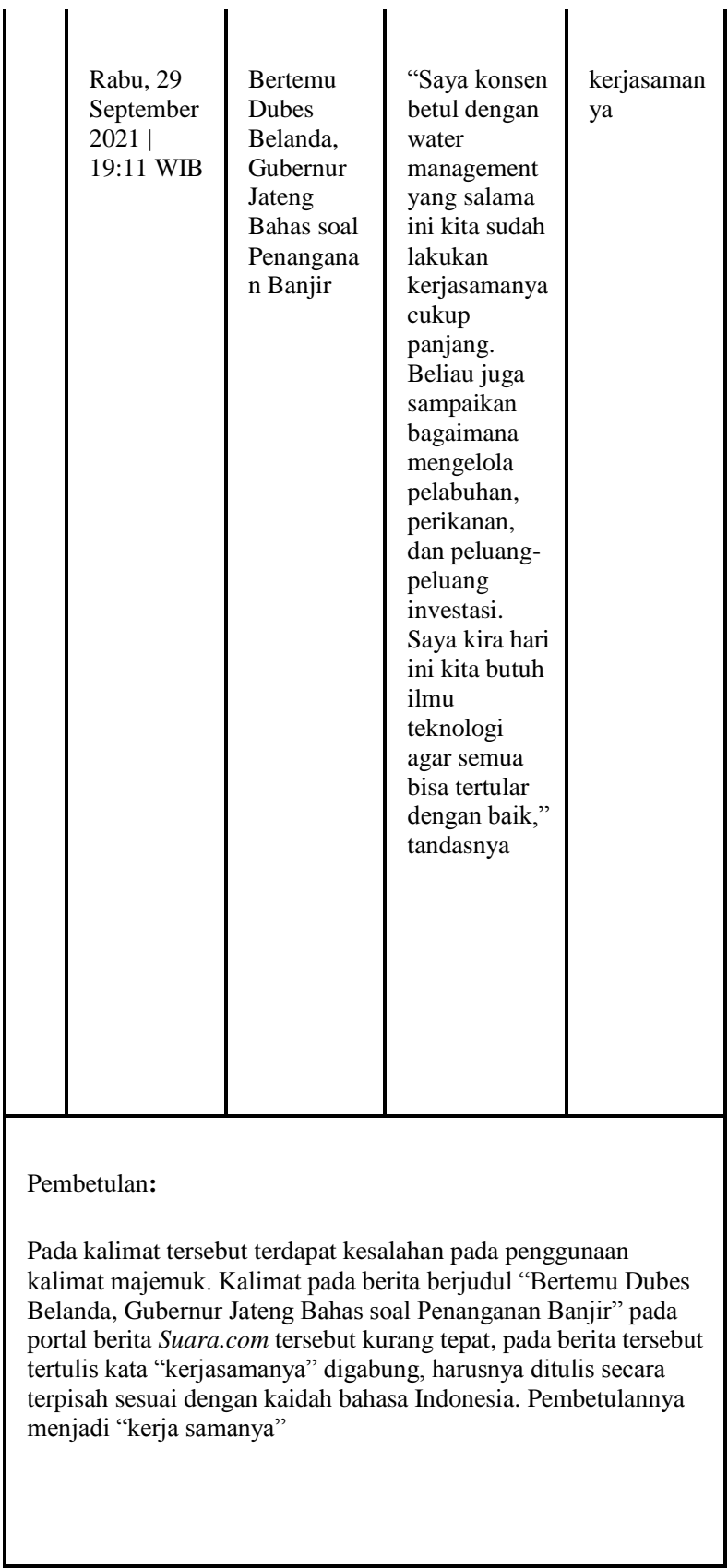

\section{Penggunaan Afiksasi}

\section{Tabel 3. Kesalahan Penggunaan} Afiksasi

Kesalahan dalam kategori
penulisan kesalahan penggunaan
afiksasi pada portal berita online
Suara.com. Dalam kategori ini,


Volume 2, Nomor 2, Desember 2021

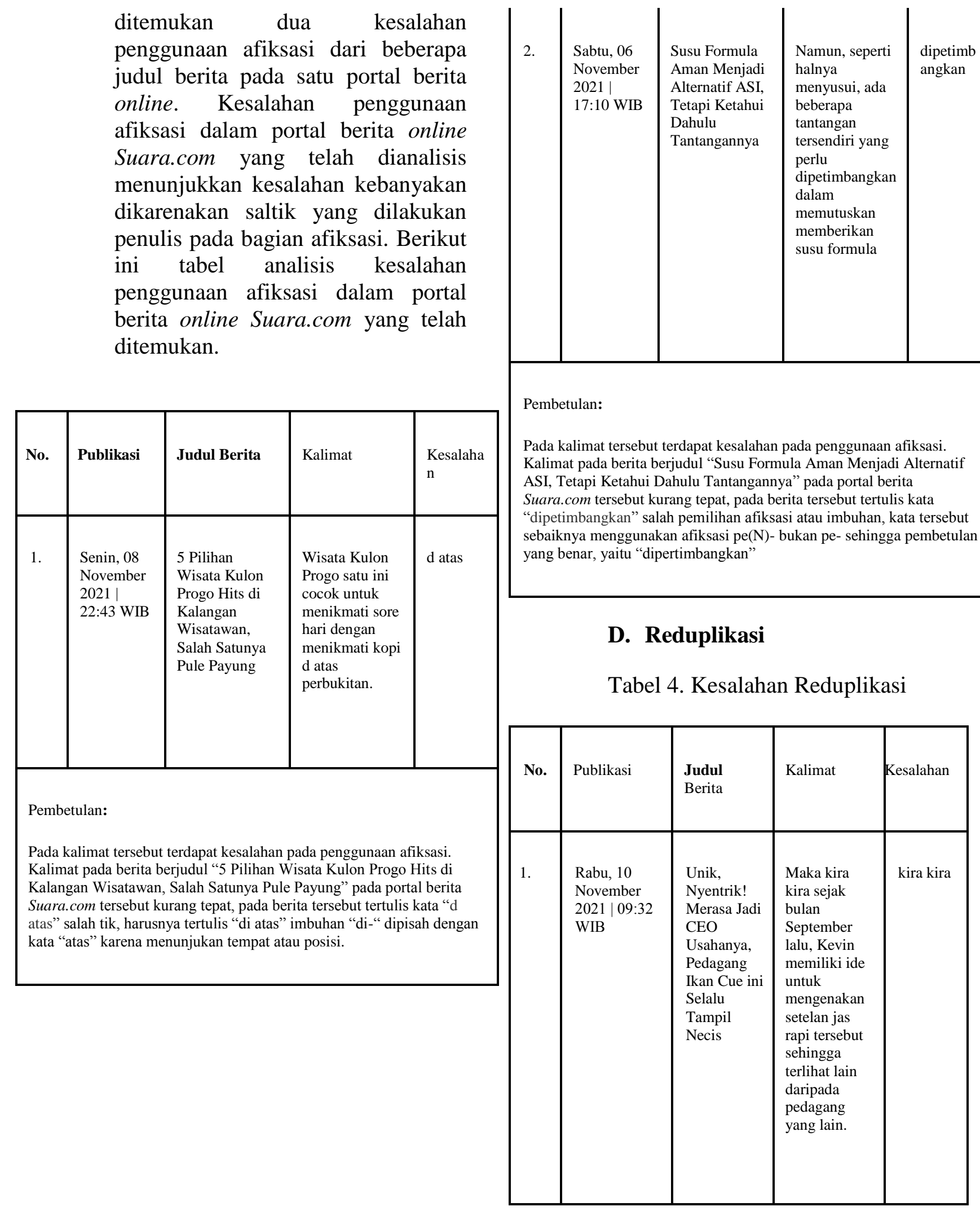


Pembetulan:

Pada kalimat tersebut terdapat kesalahan pada penggunaan reduplikasi. Kalimat pada berita berjudul "Unik, Nyentrik! Merasa Jadi CEO Usahanya, Pedagang Ikan Cue ini Selalu Tampil Necis" pada portal berita Suara.com tersebut kurang tepat, pada berita tersebut tertulis kata "kira kira" tidak memakai tanda hubung, harusnya tertulis "kira-kira". Terdapat penambahan tanda hubung, untuk menghubungkan dua kata.

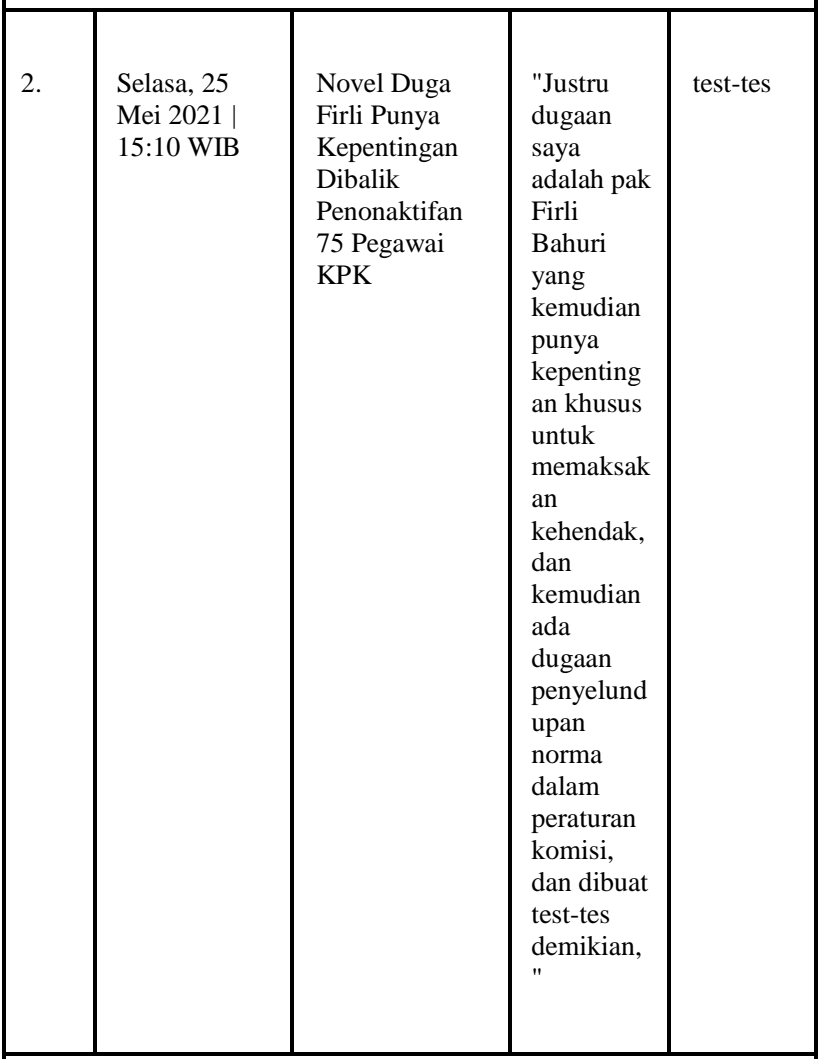

Pembetulan:

Pada kalimat tersebut terdapat kesalahan pada penggunaan reduplikasi. Kalimat pada berita berjudul "Novel Duga Firli Punya Kepentingan Dibalik Penonaktifan 75 Pegawai KPK" pada portal berita Suara.com tersebut kurang tepat, pada berita tersebut tertulis kata "test-tes" salah tik, seharusnya tertulis "tes-tes"

\section{E. Afiksasi yang Tidak Luluh}

Tabel 5. Kesalahan Afiksasi

yang Tidak Luluh

\begin{tabular}{|c|c|c|c|c|}
\hline No. & Publikasi & $\begin{array}{l}\text { Judul } \\
\text { Berita }\end{array}$ & Kalimat & Kesalahan \\
\hline 1. & $\begin{array}{l}\text { Jum'at, } 12 \\
\text { November } \\
2021 \mid 14: 01 \\
\text { WIB }\end{array}$ & $\begin{array}{l}\text { Usut } \\
\text { Temuan } \\
\text { Uang saat } \\
\text { OTT Anak } \\
\text { Alex } \\
\text { Noerdin, } \\
\text { KPK } \\
\text { Periksa } \\
\text { Sejumlah } \\
\text { Pejabat } \\
\text { hingga } \\
\text { Pengacara }\end{array}$ & $\begin{array}{l}\text { "Tim } \\
\text { Penyidik } \\
\text { mengkonfirm } \\
\text { asi yang } \\
\text { bersangkutan } \\
\text { antara lain } \\
\text { terkait dengan } \\
\text { barang bukti } \\
\text { yang } \\
\text { ditemukan } \\
\text { dan } \\
\text { diamankan } \\
\text { pada saat } \\
\text { dilakukan } \\
\text { penangkapan } \\
\text { tersangka } \\
\text { DRA (Dodi } \\
\text { Reza Alex } \\
\text { Noerdin)," }\end{array}$ & $\begin{array}{l}\text { mengkonfir } \\
\text { masi }\end{array}$ \\
\hline \multicolumn{5}{|c|}{ Pembetulan: } \\
\hline \multicolumn{5}{|c|}{$\begin{array}{l}\text { Pada kalimat tersebut terdapat kesalahan pada penggunaan reduplikasi. } \\
\text { Kalimat pada berita berjudul "Usut Temuan Uang saat OTT Anak } \\
\text { Alex Noerdin, KPK Periksa Sejumlah Pejabat hingga Pengacara" pada } \\
\text { portal berita Suara.com tersebut kurang tepat, pada berita tersebut } \\
\text { tertulis kata "mengkonfirmasi" tidak luluh, seharusnya kata tersebut } \\
\text { diluluhkan sehingga tertulis "mengonfirmasi" }\end{array}$} \\
\hline
\end{tabular}




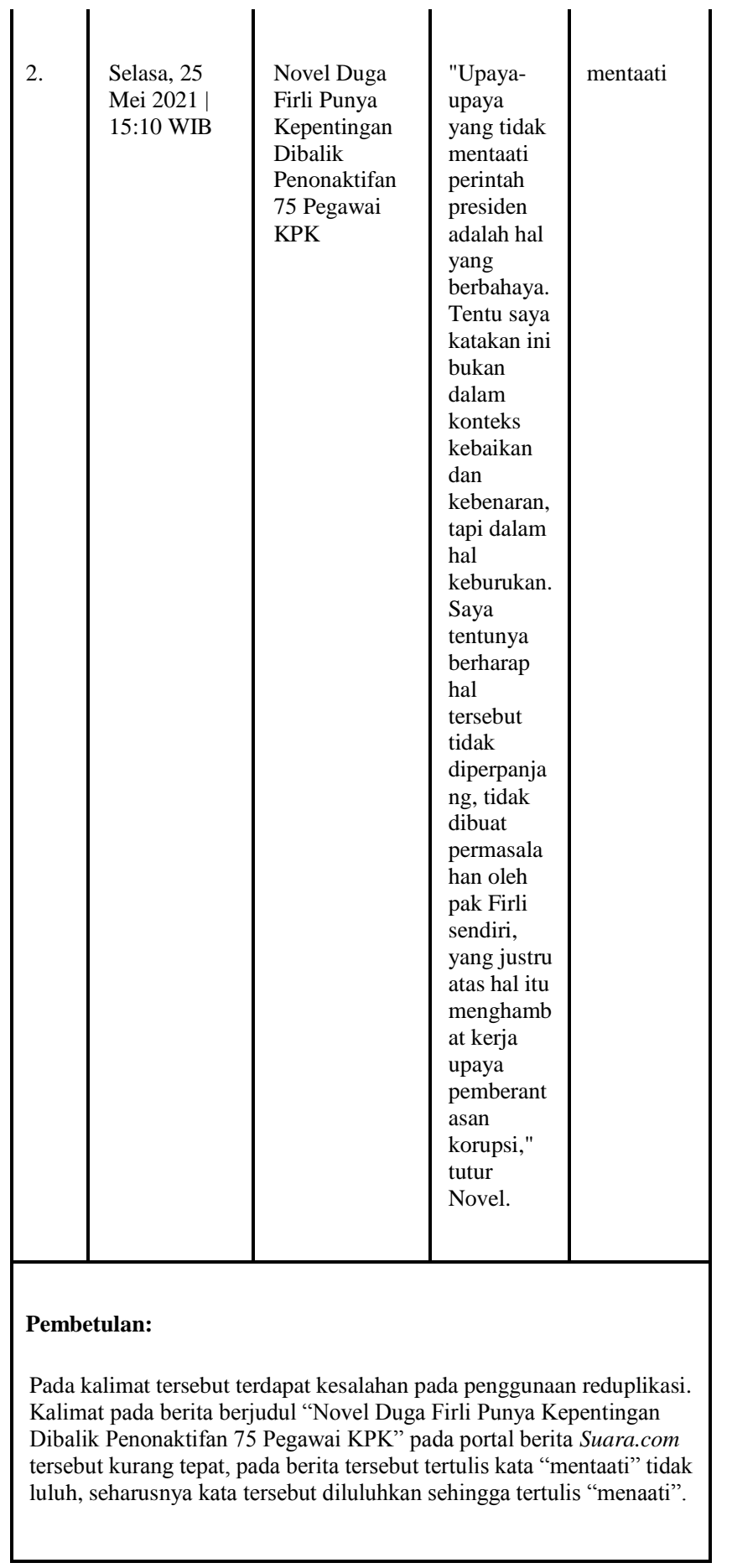

Berikut ini hasil ringkasan keseluruhan data kesalahan berbahasa dalam bidang tataran morfologi yang telah ditemukan penulis dalam portal berita online Suara.com.

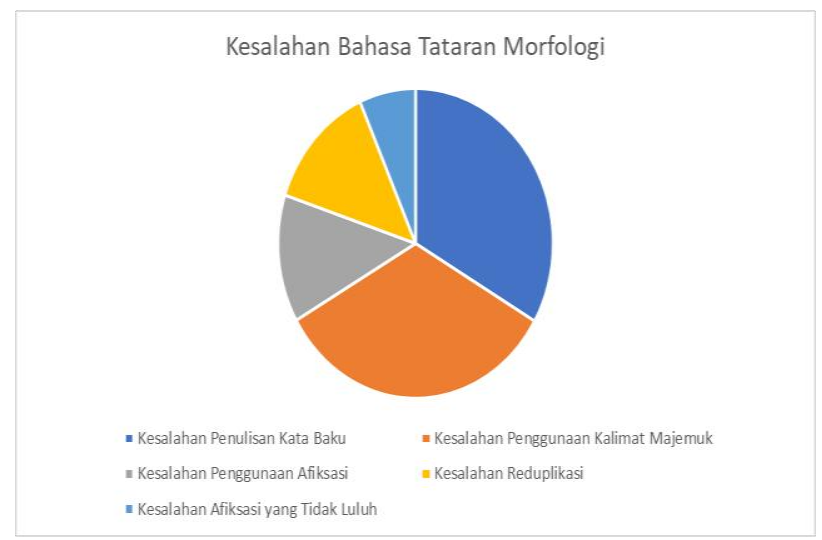

Gambar 1. Rekap Kesalahan Bahasa Tataran Morfologi

Berdasarkan hasil analisis yang telah dikemukakan sebelumnya, dapat diketahui bahwa kesalahan tataran morfologi yang terdapat pada portal berita online Suara.com lebih dominan pada aspek penulisan kata baku dan kata majemuk, masing-masing berjumlah 5 kesalahan tataran morfologi yang berhasil ditemukan. Sementara itu, kesalahan pada aspek afiksasi yang tidak luluh tidak terlalu banyak dijumpai pada portal berita online Suara.com. Hasil analisis ini berbeda dengan penelitian yang telah dilakukan oleh (Sari, dkk., 2020) pada portal berita Radar Solo, yang mana dalam penelitian tersebut kesalahan tataran morfologi justru dominan pada penghilangan prefiks dan sufiks. Sementara itu, pada aspek bunyi yang seharusnya luluh tidak diluluhkan menjadi kesalahan tataran morfologi yang paling sedikit dijumpai pada portal berita Radar Solo.

\section{SIMPULAN}

Berdasarkan dari hasil analisis penelitian yang telah dianalisis, dapat disimpulkan masih banyak terjadi kesalahan yang ditemukan di tiap kata dan kalimat dalam portal berita online Suara.com. Terjadi kesalahan dalam bidang morfologi dan EBI meliputi 
kesalahan pada penulisan kata baku, kesalahan penggunaan kalimat majemuk, penggunaan afiksasi, reduplikasi, dan afiksasi yang tidak luluh. Kesalahan tersebut banyak dilatar belakangi dengan kesalahan penulisan, penggunaan susunan kalimat dan luputnya editor dalam proses penyuntingan naskah, banyak dijumpai salah ketik, dan penggunaan spasi yang seharusnya juga diperhatikan dalam penggunaan bahasa yang baik dan benar. Sementara itu, pada penelitian yang berjudul "Analisis Kesalahan Morfologi Kata Pada Laman Berita Daring Publikasi Online.id' ditemukan sejumlah tiga macam kesalahan dalam tataran morfologi berjumlah 11 temuan data, yakni jenis kesalahan afiksasi, pemajemukan, dan reduplikasi. Dari penelitian tersebut yang paling banyak ditemui, yaitu kesalahan afiksasi mengenai kesalahan penulisan prefiks atau imbuhan yang ditambahkan pada bagian awal sebuah kata. (Utami, Dkk 2021)

Oleh karena itu, baiknya penulis lebih teliti dan memahami konsep penulisan dan konsep berbahasa yang baik. Selain agar pembaca mudah memahami, penulisan juga perlu diperhatikan untuk mempertahankan kaidah dan kebakuan bahasa. Editor harus bekerja lebih teliti dan memahami dengan baik kaidah kebahasaan yang sudah ada. Melalui pemahaman tersebut akan memberikan dampak yang positif bagi berlangsungnya artikel yang berkualitas dengan memperhatikan konteks dan penulisannya.

\section{DAFTAR PUSTAKA}

Dewi, L. S. (2020). Analisis Kesalahan Berbahasa Indonesia. Medan: Guepedia.
Indihadi, D. (2011). Analisis Kesalahan Berbahasa. Bandung: Universitas Pendidikan Indonesia.

Sitepu, T., \& Rita. (2017). Bahasa Indonesia sebagai Media Primer komunikasi Pembelajaran. BAHASTRA, 67-73.

Wiratno, T., \& Santosa, R. (2011). Pengantar Linguistik Umum. Jakarta: Universitas Terbuka.

M.Rais Almajid, W. M. (2020). Analisis Kesalahan Afiks pada Berita Babe.com Periode Januari-April 2020. Jurnal Lingue, 13-22.

Sari, S., Qoryah, A., \& Aprilia, O. (2020). Analisis Kesalahan Berbahasa Bidang Morfologi pada Portal Radar Solo. Imajeri: Jurnal Pendidikan Bahasa dan Sastra Indonesia, 82-92.

Utami Marinka Putri, M. M. (2021). Analisis Kesalahan Morfologi Kata Pada Laman Berita Daring. Jurnal Skripta, 45-51.

https://www.suara.com/lifestyle/2021/11/08/ 224359/5-pilihan-wisata-kulonprogo-hits-di-kalangan-wisatawansalah-satunya-pule-payung, diakses pada 10 November 2021.

https://www.suara.com/news/2021/09/29/19

$1136 /$ bertemu-dubes-belandagubernur-jateng-bahas-soalpenanganan-banjir?page=all, diakses pada 10 November 2021.

\section{https://www.suara.com/health/2021/11/06/1}

71051/susu-formula-aman-menjadialternatif-asi-tetapi-ketahui-dahulutantangannya, diakses pada 10 November 2021. 
https://www.suara.com/partner/content/lomb okita/2021/11/10/190904/khidmatupacara-bendera-hari-pahlawan-dipontren-syaikh-zainuddin-nw-anjani, diakses pada 10 November 2021.

https://www.suara.com/news/2021/09/29/19 1136/bertemu-dubes-belandagubernur-jateng-bahas-soalpenanganan-banjir?page $=$ all, diakses pada 10 November 2021.

https://www.suara.com/partner/content/klikp ositif/2021/11/10/190230/63-persenlebih-masyarakat-kota-solok-sudahdivaksin, diakses pada 10 November 2021.

https://www.suara.com/news/2021/11/10/18 3920/jurnalis-tv-nasional-jadikorban-pelecehan-seksual-di-pasar- rawajati, diakses pada 10 November 2021.

https://bekaci.suara.com/read/2021/11/10/09 3220/unik-nyentrik-merasa-jadi-ceousahanya-pedagang-ikan-cue-iniselalu-tampil-necis, diakses pada 11 November 2021.

https://www.suara.com/news/2021/11/12/14 0115/usut-temuan-uang-saat-ottanak-alex-noerdin-kpk-periksasejumlah-pejabat-hingga-pengacara, diakses pada 11 November 2021.

https://www.suara.com/news/2021/05/25/15 1000/novel-duga-firli-punyakepentingan-dibalik-penonaktifan75-pegawai-kpk?page=all, diakses pada $11 \quad$ November 202 